\title{
PENGARUH LIKUIDITAS (CURRENT RATIO) TERHADAP RETURN SAHAM: PERAN PEMEDIASI PROFITABILITAS (RETURN ON EQUITY) PADA PERUSAHAAN SUB SEKTOR KONSTRUKSI BANGUNAN DI BURSA EFEK INDONESIA PERIODE 2016-2018
}

\author{
Taufik Hidayat
}

\author{
Universitas Ahmad Dahlan \\ taufik.hidayat@mm.uad.ac.id
}

\begin{abstract}
This study aims to determine the effect of the liquidity ratio (CR) on stock returns with the role of profitability (ROE) as a mediator. This study takes the object of building construction sub-sector companies listed on the Indonesia Stock Exchange for the period of 2016-2018. The population in this research is all companies in the building construction sub sector listed on the Indonesia Stock Exchange in the 2016-2018 period as many as 17 companies. The sampling technique uses purposive sampling using several criteria, namely the building construction sub-sector companies listed on the Indonesia Stock Exchange in the 2016-2018 period, companies that submit financial reports during the research period and companies that have positive net income reports. The number of samples that fit the criteria were 10 companies. The data analysis tool uses panel data regression analysis using Eviews 6. The results of the study show that the current ratio has a negative effect on stock returns, the current ratio has a positive effect on return on equity, return on equity has a negative effect on stock returns. The result also showed that return on equity hasn't mediating effect of current ratio on stock return.
\end{abstract}

Keywords: Liquidity Ratio (CR); Profitability Ratio (ROE); Stock Return.

PENDAHULUAN

Pasar modal (capital market) menurut Darmadji (2012) adalah pasar untuk berbagai instrumen keuangan jangka panjang yang bisa diperjualbelikan, baik dalam bentuk utang, Saham, instrumen derivatif, maupun instrumen lainnya. Selanjutnya, Pasar modal menurut Fahmi (2012) adalah tempat berbagai pihak, khususnya perusahaan menjual Saham (stock) dan obligasi (bond), dengan tujuan dari hasil penjualan tersebut nantinya akan digunakan sebagai tambahan dana untuk memperkuat modal perusahan. Dari beberapa pengertian di atas, dapat disimpulkan bahwa pasar modal (capital market) adalah tempat diperjualbelikannya efek.

Lebih lanjut, dengan adanya pasar modal maka investor dapat menanamkan investasinya pada perusahaan untuk memperoleh kehidupan yang lebih baik di waktu yang akan datang dari hasil pengembalian (return) saham (Tandelilin, 2010). Fahmi (2012) mendefinisikan Saham sebagai kertas tanda bukti penyertaan kepemilikan modal atau dana pada suatu perusahaan yang tercantum dengan jelas nilai nominal, nama perusahaan dan diikuti dengan hak dan kewajiban yang jelas kepada setiap pemegangnya. Pendapat lain disampaikan Martalena (2011) bahwa Saham dapat didefinisikan sebagai tanda penyertaan 
Pengaruh Likuiditas (Current Ratio) Terhadap Return Saham: Peran Pemediasi Profitabilitas (Return On Equity) Pada Perusahaan Sub Sektor Konstruksi Bangunan Di Bursa Efek Indonesia Periode 2016-2018

modal seseorang atas pihak (badan usaha) dalam suatu perusahaan atau perseroan terbatas dengan menyertakan modal, maka pihak tersebut memiliki klaim atas pendapatan perusahaan. Dari definisi di atas, dapat disimpulkan bahwa saham adalah tanda bukti kepemilikan suatu perusahaan atas investasi yang diberikan.

Samsul (2006) menjelaskan bahwa return saham adalah pendapatan yang dinyatakan dalam persentase dari modal awal investasi. Pendapatan investasi dalam Saham ini merupakan keuntungan yang diperoleh dari jual beli saham, dimana jika untung disebut capital gain dan jika rugi disebut capital loss. Dari pengertian di atas dapat disimpulkan bahwa return saham merupakan hasil yang diperoleh investor dari investasi yang ditanamkan kepada perusahaan.

Fahmi (2012) mengatakan bahwa salah satu faktor yang dapat mempengaruhi return saham adalah kinerja keuangan perusahaan yang dapat dianalisis dari laporan keuangan perusahaan. Kinerja keuangan merupakan gambaran kondisi keuangan perusahaan pada suatu periode tertentu menyangkut aspek penghimpunan dana maupun penyaluran dana, yang biasanya diukur dengan indikator kecukupan modal, likuiditas, dan profitabilitas (Jumingan, 2006). Analisis laporan keuangan perusahaan dapat dilihat dari rasio keuangan dalam perusahaan, seperti rasio likuiditas, rasio aktivitas, rasio solvabilitas serta rasio profitabilitas (Munawir, 2010).

Penelitian yang sudah dilakukan oleh para peneliti sebelumnya telah menguji pengaruh rasio likuiditas (CR) terhadap return saham (Suantari, 2016 dan Tumonggor, 2017), pengaruh rasio profitabilitas (ROE) terhadap return saham (Andansari, 2016 dan Hidajat, 2012), pengaruh rasio likuiditas (CR) terhadap rasio profitabilitas (ROE) (Kartikaningsih, 2013 dan Halin, 2016). Secara lebih dalam, penelitian ini ingin menguji konsistensi penelitian terdahulu dengan menggunakan konteks penelitian yang berbeda yaitu pada perusahaan sub sektor konstruksi bangunan yang terdaftar di Bursa Efek Indonesia pada tahun 2016-2018.

Teori yang digunakan untuk menjelaskan pengaruh rasio likuiditas (Current Ratio) terhadap return saham dengan rasio profitabilitas (Return On Equity) sebagai pemediasi, yaitu menggunakan teori sinyal (signaling theory) yang menjelaskan mengenai tindakan yang diambil oleh manajemen perusahaan yang memberikan petunjuk kepada investor tentang bagaimana manajemen memandang prospek perusahaan (Besley, 2008).

Sinyal yang diberikan perusahaan dapat berupa sinyal baik dan sinyal buruk. Ketika perusahaan memberikan sinyal baik, maka akan menarik minat para investor sehingga harga saham perusahaan tentu ikut meningkat. Sebaliknya, ketika perusahaan memberikan sinyal buruk, maka akan mengurangi minat dari investor dan harga Saham perusahaan juga akan ikut menurun. Ketika harga saham perusahaan meningkat, tentu besarnya pengembalian (return) saham juga akan ikut meningkat.

Dalam penelitian ini, peneliti akan menganalisis pengaruh rasio likuiditas terhadap return saham dengan rasio profitabilitas sebagai variabel mediasi dengan objek penelitian perusahaan sub sektor konstruksi bangunan yang terdaftar di Bursa Efek Indonesia tahun pengamatan 2016-2018. Peneliti tertarik untuk meneliti pada perusahaan sub sektor konstruksi bangunan dengan beberapa alasan.

Pertama, penelitian yang menguji pengaruh rasio likuiditas terhadap return saham dengan rasio profitabilitas sebagai variabel mediasi pada perusahaan sub sektor konstruksi bangunan pada periode pengamatan tahun 2016-2018 belum pernah diteliti oleh peneliti terdahulu. Kedua, data yang bersumber dari Bappenas (2019) menunjukkan rancangan pembangunan infrastruktur di Indonesia pada tahun 2015-2018 meliputi 
pembangunan jalan raya, bandara, pelabuhan, rel kereta api, dan angkutan kota seperti yang dijelaskan pada tabel 1. Hal ini menunjukkan bahwa pertumbuhan sarana dan prasarana infrastruktur di Indonesia sedang mengalami peningkatan dan perbaikan sehingga hal ini menarik untuk diteliti terutama sektor likuiditas, profitabiltas, dan return saham perusahaan yang berada pada sub sektor konstruksi bangunan.

\section{Tabel 1. Rencana Pembangunan Infrastruktur Di Indonesia Tahun 2015-2018}

\begin{tabular}{|l|}
\hline Pembangunan Jalan Baru (2650 Km) \\
\hline Pembangunan Jalan Toll (1000 Km) \\
\hline Pembangunan 15 Bandara Baru \\
\hline Pembangunan 24 Pelabuhan Kargo \\
\hline Pembangunan Jalur KA Baru (3258 Km) \\
\hline $\begin{array}{l}\text { Pembangunan } \\
\text { Penyebrangan }\end{array}$ \\
\hline Pembangunan BRT di 29 Kota Besar \\
\hline $\begin{array}{l}\text { Pembangunan Angkutan Massal (6 Kota } \\
\text { Metropolitan, 17 Kota Besar) }\end{array}$ \\
\hline
\end{tabular}

Sumber: Bappenas (2019)

Ketiga, informasi yang bersumber dari Kementerian Koordinator Bidang Perekonomian (2019) menjelaskan bahwa hingga tahun 2019, setidaknya 13\% proyek infrastruktur telah rampung. Tercatat 30 proyek selesai dari total 225 yang ditargetkan selesai pada 2019. Pembangunan bendungan mempunyai progres paling maju dengan 49,2\%. Selanjutnya pembangunan bandara $33,3 \%$ dan infrastruktur listrik menyusul $31 \%$. Untuk pembangunan jalan tol, dengan target 1.000 kilometer $(\mathrm{km})$, saat ini baru terbangun sekitar $268 \mathrm{~km}$ atau sekitar $26,8 \%$. Pembangunan pelabuhan sudah berjalan $18,3 \%$, sedangkan diposisi terakhir yaitu progres pembangunan jalur kereta api baru berjalan $15 \%$. Target jalur kereta api mencapai $3.258 \mathrm{~km}$, namun saat ini baru terealisasi sepanjang $487,7 \mathrm{~km}$.

\section{Tabel 2. Progres Pembangunan Infrastruktur Di Indonesia Tahun 2015-2018}

\begin{tabular}{|l|c|}
\hline \multicolumn{1}{|c|}{ Proyek } & Proses \\
\hline Bendungan & $49,2 \%$ \\
\hline Bandara & $33,3 \%$ \\
\hline Infastruktur Listrik & $31 \%$ \\
\hline Jalan Toll & $26,8 \%$ \\
\hline Pelabuhan & $18,3 \%$ \\
\hline Jalur Kereta Api & $15 \%$ \\
\hline
\end{tabular}

\section{Sumber: Kementerian Koordinator Bidang Perekonomian (2019)}

Berdasarkan tabel 2 di atas, peneliti menduga hal tersebut membuka peluang bagi perusahaan sub sektor konstruksi bangunan untuk mengembangkan bisnisnya. Dengan adanya rancangan pembangunan infrastruktur, peneliti menduga hal ini secara bersama-sama dapat meningkatkan kinerja keuangan perusahaan dan pada akhirnya dapat meningkatkan return saham perusahaan.

\section{REVIEW LITERATUR DAN HIPOTESIS}

\section{Landasan Teori}

1. Pasar Modal

Pasar modal secara umum adalah suatu tempat bertemunya para penjual dan pembeli untuk melakukan transaksi dalam rangka memperoleh modal. Penjual dalam pasar modal merupakan perusahaan yang membutuhkan modal (emiten), sehingga mereka berusaha untuk menjual efek-efek di pasar modal. Sedangkan pembeli (investor) adalah pihak yang ingin membeli modal di perusahaan yang menurut mereka menguntungkan (Kasmir, 2013).

\section{Return Saham}

Menurut Jogiyanto (2014) return saham merupakan hasil yang diperoleh dari investasi. Return saham dapat berupa return realisasian yang sudah terjadi atau return ekspektasian yang 
Pengaruh Likuiditas (Current Ratio) Terhadap Return Saham: Peran Pemediasi Profitabilitas (Return On Equity) Pada Perusahaan Sub Sektor Konstruksi Bangunan Di Bursa Efek Indonesia Periode 2016-2018

belum terjadi tetapi yang diharapkan akan terjadi dimasa mendatang. Ada dua komponen dalam pengambilan keputusan yaitu:

a. Untung atau rugi modal (capital gain atau loss) merupakan keuntungan (kerugian) bagi investor yang diperoleh dari kelebihan harga jual (harga beli) di atas harga beli (harga jual) yang keduanya terjadi di pasar sekunder.

b. Imbal hasil (yield) merupakan pendapatan atau aliran kas yang diterima investor secara periodik, misalnya berupa dividen atau bunga. Yield dinyatakan dalam persentase dari modal yang ditanamkan.

\section{Current Ratio (CR)}

Current Ratio menurut Harahap (2011) merupakan rasio yang menunjukan sejauh mana aktiva lancar menutupi kewajiban-kewajiban lancar. Semakin besar perbandingan aktiva lancar dengan utang lancar semakin tinggi kemampuan perusahaan menutupi kewajiban jangka pendeknya.

\section{Return On Equity (ROE)}

Return On Equity adalah rasio yang memperlihatkan sejauh manakah perusahaan mengelola modal sendiri (networth) secara efektif mengukur tingkat keuntungan dari investasi yang telah dilakukan pemilik modal sendiri atau pemegang saham (Sawir, 2003). Harjito (2014) menambahkan bahwa Return On Equity atau sering disebut Rentabilitas Modal Sendiri dimaksudkan untuk mengukur seberapa banyak keuntungan yang menjadi hak pemilik modal sendiri.

\section{Teori Sinyal (Signaling Theory)}

Menurut Jama'an (2008) teori sinyal mengemukakan tentang bagaimana seharusnya perusahaan memberikan sinyal kepada pengguna laporan keuangan. Sinyal ini berupa informasi mengenai apa yang sudah dilakukan oleh manajemen untuk merealisasikan keinginan pemilik. Sinyal ini dapat berupa promosi atau informasi lain yang menyatakan bahwa perusahaan tersebut lebih baik daripada perusahaan lain. Teori sinyal menjelaskan bahwa pemberian sinyal dilakukan oleh manajer untuk mengurangi asimetri informasi.

\section{Hipotesis}

\section{Pengaruh Positif Current Ratio Terhadap Return Saham}

Menurut Stice et al., (2009) Current Ratio (CR) adalah sebuah ukuran tidak langsung atas kemampuan perusahaan untuk memenuhi kewajibankewajiban yang akan datang. CR merupakan rasio yang bertujuan untuk mengukur kemampuan perusahaan dalam memenuhi kewajiban jangka pendeknya. Semakin tinggi $\mathrm{CR}$ suatu perusahaan menandakan kemampuan perusahaan dalam memenuhi kewajiban jangka pendeknya. Akibatnya risiko yang ditanggung perusahaan juga semakin kecil (Ang, 1997). Dengan demikian, risiko yang ditanggung perusahaan semakin kecil, dan secara bersamaan menarik minat investor untuk menanamkan sahamnya, sehingga memicu meningkatnya harga saham perusuhaan diikuti dengan return saham yang juga ikut meningkat.

Penelitian empiris yang dilakukan Suantari (2016) dan Tumonggor (2017) menunjukkan hasil bahwa current ratio berpengaruh positif terhadap return saham perusahaan. Hal ini sejalan dengan teori sinyal yang dikemukakan oleh Brigham (2012) bahwa ketika current ratio meningkat, maka return saham perusahaan juga akan ikut meningkat. Berdasarkan uraian di atas, dapat ditarik hipotesis:

$\mathrm{H}_{1}$ : Current Ratio berpengaruh positif terhadap Return Saham. 


\section{Pengaruh Positif Current Ratio Terhadap Return On Equity.}

Brigham (2011) mengatakan rasio likuiditas adalah rasio yang menunjukkan tentang hubungan antara kas perusahaan dengan harta lancar lainnya dengan hutang lancar. Menurut Murhadi (2013) current ratio digunakan untuk mengukur kemampuan perusahaan memenuhi liabilitas jangka pendek yang akan jatuh tempo dalam waktu satu tahun.

Menurut John et al., (2010) menyatakan bahwa sebenarnya ROE dan perputaran aktiva saling berkaitan, secara khusus jika jumlah beban tetap cukup tinggi, perputaran aktiva yang lebih tinggi meningkatkan ROE. Hal ini disebabkan oleh jarak aktivitas tertentu, proporsi peningkatan biaya lebih kecil dari penjualan. Tingkat CR yang tinggi menggambarkan kemampuan perusahaan dalam memenuhi kewajiban jangka pendeknya, sehingga mengurangi risiko perusahaan mengalami illikuid. Hal tersebut kemudian menarik minat investor untuk menanamkan saham karena risiko yang ditanggung investor akan berkurang, dan harga saham perusahaan akan meningkat. Ketika harga saham perusahaan meningkat, maka tingkat pengembalian (return) yang dihasilkan dari modal yang dimiliki perusahaan juga akan semakin besar dan pada akhirnya dapat meningkatkan ROE.

Penelitian empiris yang dilakukan oleh Kartikaningsih (2013) dan Halin (2016) menunjukkan hasil bahwa current ratio berpengaruh positif terhadap return on equity. Hal ini sejalan dengan teori sinyal yang dikemukakan oleh Brigham (2012) bahwa ketika current ratio meningkat, maka return on equity perusahaan juga akan ikut meningkat. Berdasarkan uraian di atas, dapat ditarik hipotesis:
$\mathrm{H}_{2}$ : Current Ratio berpengaruh positif terhadap Return On Equity.

\section{Pengaruh Positif Return On Equity Terhadap Return Saham.}

Return on equity adalah rasio yang memperlihatkan sejauh manakah perusahaan mengelola modal sendiri (net worth) secara efektif, mengukur tingkat keuntungan dari investasi yang telah dilakukan pemilik modal sendiri atau pemegang saham perusahaan (Sawir, 2009).

Tingkat ROE yang tinggi menggambarkan kemampuan perusahaan dalam menghasilkan laba dari modal yang dimiliki. Jika perusahaan dapat menghasilkan laba yang tinggi, maka akan memicu meningkatnya permintaan saham oleh investor, sehingga harga saham akan naik dan diikuti dengan return saham perusahaan juga akan ikut meningkat. Penelitian empiris yang dilakukan oleh Andansari (2016) dan Hidajat (2018) menunjukkan hasil bahwa return on equity berpengaruh positif terhadap return saham perusahaan. Hal ini sejalan dengan teori sinyal yang disampaikan Brigham (2012) bahwa ketika return on equity meningkat, maka return saham perusahaan juga akan ikut meningkat. Berdasarkan uraian di atas, dapat ditarik hipotesis:

$\mathrm{H}_{3}$ : Return On Equity berpengaruh positif terhadap Return Saham.

\section{Peran Pemediasi Return On Equity Pada Pengaruh Positif Current Ratio Terhadap Return Saham.}

Nilai current ratio yang tinggi pada perusahaan menandakan kemampuan perusahaan dalam memenuhi kewajiban jangka pendeknya. Ketika perusahaan dinilai mampu memenuhi kewajiban jangka pendeknya, maka akan meningkatkan minat dari 
Pengaruh Likuiditas (Current Ratio) Terhadap Return Saham: Peran Pemediasi Profitabilitas (Return On Equity) Pada Perusahaan Sub Sektor Konstruksi Bangunan Di Bursa Efek Indonesia Periode 2016-2018

para investor untuk menanam saham pada perusahaan. Ketika banyak investor menanamkan sahamnya pada perusahaan, maka harga saham perusahaan tersebut akan naik, serta diikuti dengan naiknya return on equity dan pada akhirnya dapat meningkatkan return saham. Peran pemediasi return on equity dapat dijelaskan bahwa meningkatkannya nilai current ratio dapat meningkatkan juga nilai return on equity dan pada akhirnya diikuti dengan meningkatnya nilai return saham perusahaan. Berdasarkan uraian di atas, dapat ditarik hipotesis:

$\mathrm{H}_{4}$ : Peran pemediasi Return On Equity pada pengaruh positif Current Ratio terhadap Return Saham.

\section{Model Penelitian}

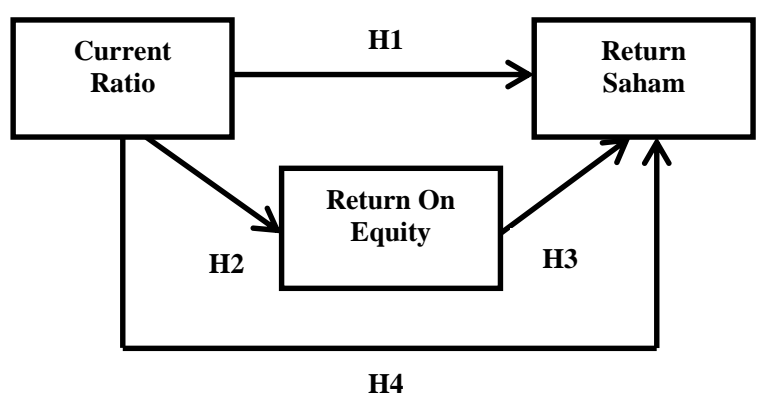

Gambar 1. Model Penelitian

\section{METODE PENELITIAN}

\section{Populasi dan Sampel}

Populasi adalah wilayah generalisasi yang terdiri atas obyek atau subyek yang mempunyai kualitas dan karakteristik tertentu yang ditetapkan oleh peneliti untuk dipelajari dan kemudian ditarik kesimpulannya (Sugiyono, 2005). Populasi yang digunakan dalam penelitian ini adalah seluruh perusahaan sub sektor konstruksi bangunan pada Bursa Efek Indonesia periode 2016-2018 yang berjumlah 17 perusahaan.
Sampel adalah sebagian objek yang diambil dari keseluruhan objek yang diteliti dan dianggap mewakili seluruh populasi (Notoatmojo, 2003). Sampel pada penelitian ini ditentukan dengan menggunakan teknik purposive sampling, yaitu metode pemilihan sampel tidak secara acak yang informasinya diperoleh dengan menggunakan pertimbangan tertentu dimana perusahaan dipilih berdasarkan kriteria-kriteria tertentu untuk mendapatkan sampel yang representatif (Supomo, 2002). Kriteria yang digunakan dalam penelitian ini yaitu:

1. Perusahaan sub sektor konstruksi bangunan yang terdaftar di Bursa Efek Indonesia pada periode 2016-2018.

2. Perusahaan sub sektor konstruksi bangunan yang menyampaikan laporan data keuangan pada periode 2016-2018.

3. Perusahaan sub sektor konstruksi bangunan yang mempunyai laporan laba bersih positif pada periode 2016-2018.

Berdasarkan kriteria di atas, jumlah perusahaan yang memenuhi kriteria untuk dilakukan penelitian sebanyak 10 perusahaan. Berikut adalah daftar 10 perusahaan yang menjadi objek penelitian:

Tabel 3. Daftar Nama Perusahaan Sub Sektor Konstruksi Bangunan

\begin{tabular}{|c|c|}
\hline Kode & Nama Perusahaan \\
\hline ACST & Acset Indonusa Tbk. \\
\hline ADHI & Adhi Karya (Persero) Tbk. \\
\hline IDPR & Indonesia Pondasi Raya Tbk. \\
\hline MTRA & Mitra Pemuda Tbk. \\
\hline NRCA & Nusa Raya Cipta Tbk. \\
\hline PBSA & Paramita Bangun Sarana Tbk. \\
\hline PTPP & PP (Persero) Tbk. \\
\hline TOTL & Total Bangun Persada Tbk. \\
\hline WIKA & Wijaya Karya (Persero) Tbk. \\
\hline WSKT & Waskita Karya (Persero) Tbk. \\
\hline
\end{tabular}

Sumber: Bursa Efek Indonesia (2019) 


\section{Definisi Operasional}

\section{Variabel Independen}

Variabel independen yang digunakan dalam penelitian ini adalah Current Ratio (CR). Current ratio merupakan ukuran yang paling umum digunakan untuk mengetahui kesanggupan memenuhi kewajiban jangka pendek, karena rasio ini menunjukan seberapa jauh tuntutan dari kreditor jangka pendek dipenuhi oleh aktiva yang diperkirakan menjadi uang tunai dalam periode yang sama dengan jatuh tempo utang (Sawir, 2003).

Current Ratio $(\mathrm{CR})=\frac{\text { Aktiva Lancar }}{\text { Hutang Lancar }}$

\section{Variabel Dependen}

Variabel dependen yang digunakan dalam penelitian ini adalah return saham. Menurut Brigham (2006) Return saham atau tingkat pengembalian Saham adalah selisih antara jumlah yang diterima dan jumlah yang diinvestasikan, dibagi dengan jumlah yang diinvestasikan. Rumus return saham yaitu harga saham tahun penelitian dikurangi dengan harga Saham tahun sebelumnya, kemudian dibagi harga saham tahun sebelumnya.

\section{Variabel Mediasi}

Variabel mediasi yang digunakan dalam penelitian ini adalah Return On Equity (ROE). Return On Equity adalah perbandingan antara jumlah profit yang tersedia bagi pemilik modal sendiri di satu pihak dengan jumlah modal sendiri yang menghasilkan laba tersebut di lain pihak. Atau dapat dikatakan bahwa rentabilitas modal sendiri adalah kemampuan suatu perusahaan dengan modal sendiri yang bekerja di dalamnya untuk menghasilkan keuntungan (Riyanto, 2001).

Return On Equity $(\mathrm{ROE})=\frac{\text { Net Income }}{\text { Equity }}$

\section{Teknik Analisis Data}

\section{Analisis Statistik Deskriptif}

Sugiyono (2005) mengatakan bahwa analisis statistik deskriptif adalah suatu metode yang digunakan untuk menganalisis suatu hasil penelitian tetapi tidak digunakan untuk membuat kesimpulan yang lebih luas. Pendapat lain disampaikan oleh Whitney (1960) bahwa analsis deskriptif adalah pencarian fakta dengan interpretasi yang tepat.

\section{Analisis Asumsi Klasik}

\section{a. Normalitas}

\begin{tabular}{llr}
\multicolumn{1}{c}{ Uji ini bertujuan untuk } \\
mengetahui & apakah & variabel \\
dependen & dan & independen \\
berdistribusi & normal atau tidak
\end{tabular} (Ghozali, 2011). Kriteria yang digunakan dalam uji normalitas yatitu apabila nilai probabilitas Jarque-Bera (J-B) lebih besar dari alpha 5\% (prob. $\mathrm{J}-\mathrm{B}>0,05)$, maka data berdistribusi normal (Kusuma, 2012).

\section{b. Autokorelasi}

Uji ini bertujuan untuk mengetahui hubungan antara residual satu observasi dengan observasi lainnya (Kusuma, 2012). Keputusan yang digunakan dalam uji ini adalah: Jika Prob. Chi Square > 0,05, maka tidak ada autokorelasi.

Jika Prob. Chi Square < 0,05, maka ada autokorelasi.

\section{c. Heteroskedastisitas}

Uji heteroskedastisitas adalah uji untuk mengetahui kondisi dimana nilai varians error untuk setiap data pengamatan tidak konstan (Kusuma, 2012). Dalam penelitian ini, peneliti menggunakan metode BreuschPagan-Godfrey (BPG), dimana metode ini memerlukan pengurutan dan penghilangan data. Keputusan yang diambil dalam pengujian ini adalah sebagai berikut: 
Pengaruh Likuiditas (Current Ratio) Terhadap Return Saham: Peran Pemediasi Profitabilitas (Return On Equity) Pada Perusahaan Sub Sektor Konstruksi Bangunan Di Bursa Efek Indonesia Periode 2016-2018

Jika Prob. Chi Square ( $p$-value) $>$ 0,05 , maka tidak terjadi heteroskedastisitas

Jika Prob. Chi Square (p-value) < 0,05 , maka terjadi heteroskedastisitas

\section{d. Multikolinieritas}

Uji multikolinieritas bertujuan untuk mengetahui korelasi atau hubungan diantara variabel independen. Multikolinieritas hanya terjadi pada regresi majemuk, karena melibatkan beberapa variabel independen sehingga tidak terjadi pada regresi sederhana (Kusuma, 2012). Dapat dikatakan mengalami masalah multikolinieritas apabila variabel independen saling berkorelasi lebih dari 0,90 (> 90\%).

\section{Analisis Regresi Data Panel}

Menurut Kuncoro (2011) regresi data panel adalah kombinasi antara data silang tempat (cross section) dengan data runtut waktu (time series). Widarjono (2009) menyatakan bahwa terdapat beberapa metode yang biasa digunakan dalam mengestimasi model regresi dengan data panel, yaitu pooling least square (Common Effect), pendekatan efek tetap (Fixed Effect), pendekatan efek random (Random Effect).

\section{Uji Hipotesis}

\section{Uji Parsial (Uji T)}

Uji parsial (uji T) digunakan untuk mengetahui pengaruh dari masingmasing variabel independen terhadap variabel dependen. Kriteria dalam uji $\mathrm{T}$ ini adalah sebagai berikut:

- Jika nilai koefisien bernilai positif, maka variabel independen berpengaruh positif terhadap variabel dependen.

- Jika nilai koefisien bernilai negatif, maka variabel independen berpengaruh negatif terhadap variabel dependen.
- Jika nilai probabilitas <0,05, maka variabel independen berpengaruh signifikan terhadap variabel dependen.

- Jika nilai probabilitas > 0,05, maka variabel independen tidak berpengaruh signifikan terhadap variabel dependen.

\section{Uji Koefisien Determinasi}

Uji ini bertujuan untuk mengetahui seberapa besar variabel independen dapat mempengaruhi variabel dependen (Ghozali, 2011). Nilai koefisien determinasi besarnya antara 0 dan 1. Apabila nilai $\mathrm{R}^{2}$ mendekati 0 , maka kemampuan variabel independen dalam mempengaruhi variabel dependen masih terbatas. Sebaliknya, jika nilai $\mathrm{R}^{2}$ mendekati 1, maka kemampuan variabel independen dalam mempengaruhi variabel dependen cukup baik.

\section{HASIL PENELITIAN DAN PEMBAHASAN}

\section{Hasil Penelitian}

\section{Hasil Uji Statistik Deskriptif} Tabel 3. Hasil Uji Statistik Deskriptif

\begin{tabular}{|c|c|c|c|}
\hline & CR & ROE & RS \\
\hline Max & 33,16 & 23,48 & 0,53 \\
\hline Min & 0,67 & 2,58 & $-0,6$ \\
\hline
\end{tabular}

Berdasarkan tabel 3 di atas, dapat dijelaskan sebagai berikut:

a. Current Ratio (CR) memiliki nilai maksimum sebesar 33,16 yang terdapat pada PT. Paramita Bangun Sarana Tbk. pada tahun 2016, dan nilai minimun sebesar 0,67 terdapat pada PT. Acset Indonusa Tbk. pada tahun 2017.

b. Return On Equity (ROE) memiliki nilai maksimum sebesar 23,48 yang terdapat pada PT. Total Bangun Persada Tbk. pada tahun 2016, dan nilai minimum sebesar 2,58 terdapat pada PT. Indonesia Pondasi Raya Tbk. pada tahun 2018. 
c. Return Saham memiliki nilai maksimum sebesar 0,53 yang terdapat pada PT. Waskita Karya (Persero) Tbk. pada tahun 2016, dan nilai minimum sebesar $-0,6$ terdapat pada PT. Paramita Bangun Sarana Tbk. pada tahun 2018.

\section{Hasil Uji Asumsi Klasik}

a. Normalitas

Tabel 4. Hasil Uji Normalitas

\begin{tabular}{|c|c|}
\hline Jarque-Bera & 1,748205 \\
\hline Probability & 0,417236 \\
\hline
\end{tabular}

Berdasarkan hasil uji normalitas pada tabel 4, diperoleh nilai probabilitas sebesar 0,417236 yang mana lebih besar dari nilai $\alpha 5 \%$ $(0,417236>0,05)$, sehingga dapat disimpulkan bahwa data berdistribusi normal.

b. Autokorelasi

Tabel 5. Hasil Uji Autokorelasi

\begin{tabular}{|c|c|}
\hline $\begin{array}{l}\text { Prob. Chi- } \\
\text { Square }\end{array}$ & 0,2229 \\
\hline
\end{tabular}
autokorelasi pada tabel 5, diperoleh nilai Prob. Chi-Square sebesar 0,2229 yang mana lebih besar dari nilai $\alpha 5 \%$ $(0,2229>0,05)$. Artinya, data tersebut terbebas dari masalah autokorelasi.

c. Heteroskedastisitas

Tabel 6. Hasil Uji

Heteroskedastisitas

\begin{tabular}{|c|c|}
\hline Obs*R-Square & 0,388010 \\
\hline $\begin{array}{c}\text { Prob. Chi- } \\
\text { Square }\end{array}$ & 0,8237 \\
\hline \multicolumn{2}{|c|}{ Berdasarkan } \\
\hline
\end{tabular}

heteroskedastisitas pada tabel 6, diperoleh nilai Prob. Chi-Square sebesar 0,8237 yang mana lebih besar dari nilai $\alpha 5 \% \quad(0,8237>0,05)$. Artinya, data tersebut terbebas dari masalah heteroskedastisitas. d. Multikolinieritas

Tabel 7. Hasil Uji

Multikolinieritas

\begin{tabular}{|c|c|c|}
\hline & CR & ROE \\
\hline CR & 1,00000 & 0,45424 \\
\hline ROE & 0,45424 & 1,00000 \\
\hline \multicolumn{2}{|c|}{ Berdasarkan hasil uji }
\end{tabular}

multikoliniertas pada tabel 7, dapat dilihat bahwa nilai keeratan antar variabel independennya $<0,90$ (90\%). Hal ini menandakan bahwa data yang digunakan terbebas dari masalah multikolinieritas.

\section{Hasil Uji Regresi Data Panel}

a. Hasil Regresi CR Terhadap RS

Tabel 8. Hasil Regresi CR

Terhadap RS

\begin{tabular}{|c|c|}
\hline & Koefisien \\
\hline C & $-0,126231$ \\
\hline CR & 0,008788 \\
\hline
\end{tabular}

Dari hasil uji regresi variabel CR terhadap RS pada tabel 8, diperoleh persamaan:

$$
\mathrm{RS}=-0,126231+0,008788 \mathrm{CR}
$$

Nilai konstanta sebesar -0,126231. Artinya jika variabel CR bernilai 0 , maka diperoleh nilai Return Saham sebesar -0,126231. Current Ratio (CR) bernilai 0,008788. Artinya, jika CR meningkat sebesar 1 satuan, maka Return Saham juga akan meningkat sebesar 0,008788. Sebaliknya, jika CR menurun sebesar 1 satuan, maka Return Saham juga akan menurun sebesar 0,008788.

b. Hasil Regresi CR Terhadap ROE

Tabel 9. Hasil Regresi CR Terhadap ROE

\begin{tabular}{|c|c|}
\hline & Koefisien \\
\hline C & 8,765383 \\
\hline CR & 0,436619 \\
\hline
\end{tabular}

Dari hasil uji regresi variabel CR terhadap ROE pada tabel 9, diperoleh persamaan:

$\mathrm{ROE}=8,765383+0,436619 \mathrm{CR}$ 
Pengaruh Likuiditas (Current Ratio) Terhadap Return Saham: Peran Pemediasi Profitabilitas (Return On Equity) Pada Perusahaan Sub Sektor Konstruksi Bangunan Di Bursa Efek Indonesia Periode 2016-2018

Nilai konstanta sebesar 8,765383. Artinya, jika variabel CR bernilai 0 , maka diperoleh nilai ROE sebesar 8,765383. Current Ratio (CR) bernilai 0,436619. Artinya, jika nilai CR meningkat 1 satuan, maka nilai ROE juga akan meningkat sebesar 0,436619. Sebaliknya, jika nilai CR menurun 1 satuan, maka nilai ROE juga akan menurun sebesar 0,436619 .

c. Hasil Regresi ROE Terhadap RS

Tabel 10. Hasil Regresi ROE Terhadap RS

\begin{tabular}{|c|c|}
\hline & Koefisien \\
\hline C & $-0,161841$ \\
\hline ROE & 0,007205 \\
\hline
\end{tabular}

Dari hasil uji regresi variabel ROE terhadap RS pada tabel 10, diperoleh persamaan:

$\mathrm{RS}=-0,161841+0,007205 \mathrm{ROE}$

Nilai konstanta sebesar 0,161841. Artinya, jika variabel ROE bernilai 0, maka diperoleh nilai Return Saham sebesar -0,161841. Return On Equity (ROE) bernilai 0,007205. Artinya, jika nilai ROE meningkat 1 satuan, maka Return Saham akan meningkat sebesar 0,007205. Sebaliknya, jika nilai ROE menurun 1 satuan, maka Return Saham akan menurun sebesar 0,007205 .

d. Hasil Regresi CR Terhadap RS Dengan ROE Sebagai Pemediasi

Tabel 11. Hasil Regresi CR

Terhadap RS Dengan ROE Sebagai Pemediasi

\begin{tabular}{|c|c|}
\hline & Koefisien \\
\hline C & $-0,151191$ \\
\hline CR & 0,007805 \\
\hline
\end{tabular}

Dari hasil uji regresi variabel CR terhadap RS yang dimediasi oleh variabel ROE pada tabel 11, diperoleh persamaan:

$\mathrm{RS}=-0,151191+0,007805 \mathrm{CR}$

Nilai konstanta sebesar 0,151191. Artinya, jika variabel CR bernilai 0 , maka diperoleh nilai
Return Saham sebesar -0,151191. Current Ratio (CR) bernilai 0,007805. Artinya, jika nilai CR meningkat 1 satuan, maka Return Saham akan meningkat sebesar 0,007805. Sebaliknya, jika nilai CR menurun 1 satuan, maka nilai Return Saham akan menurun sebesar 0,007805 .

\section{Hasil Uji Parsial (Uji T)}

a. Hasil Uji Parsial CR Terhadap RS Tabel 12. Hasil Uji Parsial CR Terhadap RS

\begin{tabular}{|c|c|c|}
\hline & Koefisien & Probabilitas \\
\hline CR & 0,008788 & 0,1511 \\
\hline
\end{tabular}

Berdasarkan tabel 12, hasil uji hipotesis yang pertama yaitu untuk mengetahui pengaruh Current Ratio (CR) terhadap Return Saham. Hasil menunjukkan nilai koefisien sebesar 0,008788 dan nilai probabilitas sebesar 0,1511 yang artinya berpengaruh positif dan tidak signifikan, sehingga hipotesis pertama yang mengatakan Current Ratio berpengaruh positif terhadap Return Saham ditolak.

b. Hasil Uji Parsial CR Terhadap ROE

Tabel 13. Hasil Uji Parsial CR Terhadap ROE

\begin{tabular}{|c|c|c|}
\hline & Koefisien & Probabilitas \\
\hline CR & 0,436619 & 0,0040 \\
\hline
\end{tabular}

Berdasarkan tabel 13, hasil uji hipotesis yang kedua yaitu untuk mengetahui pengaruh Current Ratio (CR) terhadap Return On Equity (ROE). Hasil menunjukkan nilai koefisien sebesar 0,436619 dan nilai probabilitas sebesar 0,0040 yang artinya berpengaruh positif dan signifikan, sehingga hipotesis kedua yang mengatakan Current Ratio berpengaruh positif terhadap Return On Equity (ROE) diterima. 
c. Hasil Uji Parsial ROE Terhadap RS

Tabel 14. Hasil Uji Parsial ROE Terhadap RS

\begin{tabular}{|c|c|c|}
\hline & Koefisien & Probabilitas \\
\hline ROE & 0,007205 & 0,3563 \\
\hline \multicolumn{3}{|c|}{ Berdasarkan tabel 14, hasil uji }
\end{tabular}
hipotesis yang ketiga yaitu untuk mengetahui pengaruh Return On Equity (ROE) terhadap Return Saham. Hasil menunjukkan nilai koefisien sebesar 0,007205 dan nilai probabilitas sebesar 0,3563 yang artinya berpengaruh positif dan tidak signifikan, sehingga hipotesis ketiga yang mengatakan Return On Equity (ROE) berpengaruh positif terhadap Return Saham ditolak.

d. Hasil Uji Parsial CR Terhadap RS Dengan ROE Sebagai Pemediasi

Tabel 15. Hasil Uji Parsial CR

Terhadap RS Dengan ROE Sebagai Pemediasi

\begin{tabular}{|c|c|c|}
\hline & Koefisien & Probabilitas \\
\hline CR & 0,007805 & 0,2607 \\
\hline \multicolumn{3}{|c|}{ Berdasarkan tabel 15, hasil uji }
\end{tabular}
hipotesis yang keempat yaitu untuk mengetahui peran mediasi pada pengaruh Current Ratio terhadap Return Saham. Hasil menunjukkan nilai koefisien sebesar 0,007805 dan nilai probabilitas sebesar 0,2607 yang artinya berpengaruh positif dan tidak signifikan, sehingga hipotesis keempat yang mengatakan mediasi berperan pada pengaruh positif Current Ratio (CR) terhadap Return Saham ditolak.

\section{Hasil Uji Koefisien Determinasi}

a. Hasil R-Square CR Terhadap RS

Tabel 16. Hasil R-Square CR Terhadap RS

\begin{tabular}{|r|rr|}
\hline & \multicolumn{2}{|c|}{ R-Square } \\
\hline CR & \multicolumn{2}{c|}{0,072173} \\
\hline Nilai & R-Square & sebesar \\
0,072173 & menunjukkan & bahwa \\
variabe Current Ratio & mampu
\end{tabular}

menjelaskan Return Saham sebesar $7,21 \%$.

b. Hasil R-Square CR Terhadap ROE Tabel 17. Hasil R-Square CR Terhadap ROE

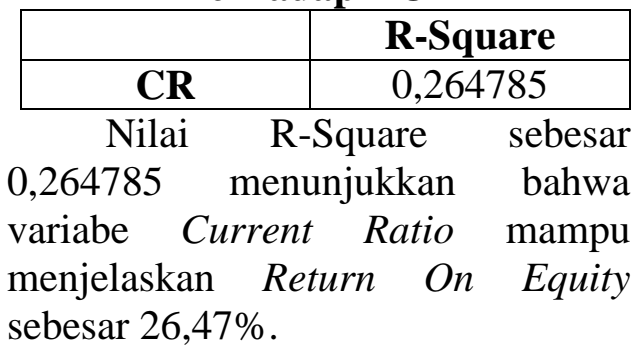

c. Hasil R-Square ROE Terhadap RS Tabel 18. Hasil R-Square ROE Terhadap RS

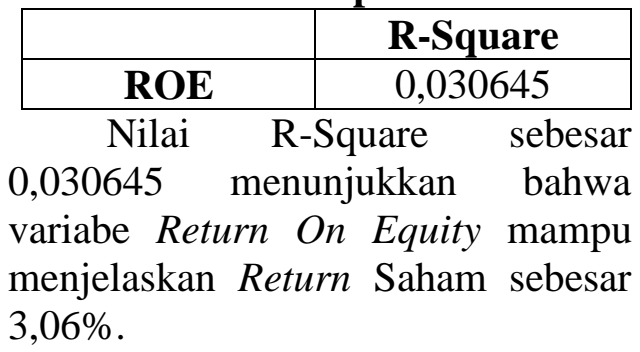

d. Hasil R-Square CR Terhadap RS Dengan ROE Sebagai Pemediasi

Tabel 19. Hasil R-Square CR Terhadap RS Dengan ROE Sebagai Pemediasi

\begin{tabular}{|c|c|}
\hline & R-Square \\
\hline CR & 0,075647 \\
\hline
\end{tabular}

Nilai R-Square sebesar 0,075647 menunjukkan bahwa variabe Current Ratio yang dimediasi oleh Return On Equity mampu menjelaskan Return Saham sebesar $7,56 \%$.

\section{Pembahasan}

1. Pengaruh Positif Current Ratio Terhadap Return Saham

Hasil pengujian hipotesis secara parsial (Uji T) Current Ratio (CR) terhadap Return Saham menunjukkan nilai koefisien sebesar 0,008788 dan nilai probabilitas sebesar 0,1511, sehingga hipotesis pertama yang mengatakan current ratio berpengaruh positif terhadap Return Saham perusahaan sub sektor konstruksi 
Pengaruh Likuiditas (Current Ratio) Terhadap Return Saham: Peran Pemediasi Profitabilitas (Return On Equity) Pada Perusahaan Sub Sektor Konstruksi Bangunan Di Bursa Efek Indonesia Periode 2016-2018

bangunan ditolak. Hasil tersebut mendukung penelitian sebelumnya yang dilakukan oleh Sugiarti (2015) dan Choirurodin (2018) dengan hasil Current Ratio (CR) tidak berpengaruh positif terhadap Return Saham.

Bagi perusahaan rasio lancar yang tinggi menunjukkan likuiditas, tetapi ia juga bisa dikatakan menunjukkan penggunaan kas dan aset jangka pendek secara tidak efisien (Ross, 2008). Rasio ini menunjukkan kemampuan perusahaan untuk memenuhi kewajiban jangka pendeknya. Suatu perusahaan yang mampu membayar belum tentu mampu memenuhi segala kewajiban keuangan yang harus dipenuhi (Harahap, 2011) karena proporsi atau distribusi dari aktiva lancar yang tidak menguntungkan, misalnya jumlah persediaan yang relatif tinggi dibandingkan dengan taksiran tingkat penjualan yang akan datang sehingga tingkat perputaran persediaan rendah menunjukkan adanya over investment dalam persediaan tersebut atau adanya saldo piutang yang besar yang mungkin sulit ditagih (Ang, 1997). Apabila aktiva lancar untuk mengurangi jumlah hutang lancar, sedangkan hutang lancar digunakan untuk menambah aktiva lancar. Maka aktiva lancar yang dimiliki perusahaan lebih kecil daripada hutang lancar, dan perusahaan mengalami kesulitan dalam mengoperasikan perusahaannya. Ini dikarenakan terlalu banyak modal kerja mengakibatkan banyak dana yang menganggur, sehingga dapat pada akhirnya dapat menurunkan laba (Tulasi, 2006).

\section{Pengaruh Positif Current Ratio Terhadap Return On Equity}

Hasil pengujian hipotesis secara parsial (Uji T) Current Ratio (CR) terhadap Return On Equity (ROE) menunjukkan nilai koefisien sebesar 0,436619 dan nilai probabilitas sebesar
0,0040, sehingga hipotesis kedua yang mengatakan current ratio berpengaruh positif terhadap return on equity perusahaan sub sektor konstruksi bangunan diterima. Hasil tersebut mendukung penelitian sebelumnya yang dilakukan oleh Kartikaningsih (2013) dan Halin (2016) dengan hasil current ratio berpengaruh positif terhadap return on equity. Tingkat $\mathrm{CR}$ yang tinggi menggambarkan kemampuan perusahaan dalam memenuhi kewajiban jangka pendeknya, sehingga mengurangi risiko perusahaan mengalami illikuid. Hal tersebut kemudian menarik minat investor untuk menanamkan saham karena resiko yang ditanggung investor akan berkurang, dan harga saham perusahaan akan meningkat. Ketika harga saham perusahaan meningkat, maka tingkat pengembalian (return) yang dihasilkan dari modal yang dimiliki perusahaan juga akan semakin besar dan pada akhirnya dapat meningkatkan ROE.

\section{Pengaruh Positif Return On Equity Terhadap Return Saham}

Hasil pengujian hipotesis secara parsial (Uji T) Return On Equity (ROE) terhadap Return Saham menunjukkan nilai koefisien sebesar 0,007205 dan nilai probabilitas sebesar 0,3563, sehingga hipotesis ketiga yang mengatakan return on equity berpengaruh positif terhadap return saham perusahaan sub sektor konstruksi bangunan ditolak. Hasil tersebut mendukung penelitian sebelumnya yang dilakukan oleh Aryaningsih (2018) dan Absari (2012) dengan hasil return on equity (ROE) berpengaruh negatif terhadap return saham. Nilai ROE termasuk salah satu tolak ukur investor untuk menjadi pertimbangan sebelum menanamkan investasi. Dari nilai ROE, calon investor bisa mempertimbangkan besaran tingkat pengembalian (return) dari hasil investasinya. Hasil ini berarti 
bahwa ROE sebagai informasi tidak direspon positif oleh para pelaku bursa, tetapi malah terjadi sebaliknya, yaitu cenderung direspon negatif. Kondisi ini disebabkan karena pola distribusi data dari return saham yang cenderung turun ketika ROE meningkat.

\section{Peran Mediasi Pada Pengaruh Positif Current Ratio Terhadap Return Saham.}

Hasil pengujian hipotesis secara parsial (Uji T) Current Ratio (CR) terhadap Return Saham yang dimediasi oleh Return On Equity (ROE) menunjukkan nilai koefisien sebesar 0,007805 dan nilai probabilitas sebesar 0,2607 sehingga hipotesis keempat yang mengatakan peran mediasi Return On Equity pada pengaruh positif Current Ratio (CR) terhadap Return Saham perusahaan sub sektor konstruksi bangunan ditolak. Hal ini menunjukkan bahwa Return On Equity tidak memediasi pada pengaruh Current Ratio terhadap Return Saham. Hal ini dapat diartikan sebagai meningkatnya current ratio perusahaan tidak serta merta dapat menaikkan return on equity dan pada akhirnya dapat menurunkan return saham.

\section{KESIMPULAN DAN SARAN}

\section{Kesimpulan}

Berdasarkan hasil analisis data yang sudah dibahas sebelumnya, maka diperoleh kesimpulan sebagai berikut:

1. Rasio likuiditas yang diukur dengan Current Ratio (CR) menunjukkan hasil bahwa terdapat pengaruh positif dan tidak signifikan CR terhadap Return saham perusahaan sub sektor konstruksi bangunan yang terdaftar di Bursa Efek Indonesia tahun 2016-2018. Hipotesis pertama yang mengatakan CR berpengaruh positif terhadap Return Saham perusahaan sub sektor konstruksi bangunan yang terdaftar di Bursa Efek Indonesia tahun 2016-2018 ditolak. Hal ini dibuktikan dengan nilai koefisien sebesar 0,008788 dan nilai probabilitas sebesar 0,1511 yang lebih besar dari nilai signifikansi $5 \%(0,1511>0,05)$.

2. Rasio likuiditas yang diukur dengan Current Ratio (CR) menunjukkan hasil bahwa terdapat pengaruh positif dan signifikan CR terhadap Return On Equity perusahaan sub sektor konstruksi bangunan yang terdaftar di Bursa Efek Indonesia tahun 2016-2018. Hipotesis kedua yang mengatakan CR berpengaruh positif terhadap Return On Equity perusahaan sub sektor konstruksi bangunan yang terdaftar di Bursa Efek Indonesia tahun 2016-2018 diterima. Hal ini dibuktikan dengan nilai koefisien sebesar 0,436619 dan nilai probabilitas sebesar 0,0040 yang lebih kecil dari nilai signifikansi $5 \%(0,0040<0,05)$.

3. Rasio solvabilitas yang diukur dengan Return On Equity (ROE) menunjukkan hasil bahwa terdapat pengaruh positif dan tidak signifikan ROE terhadap Return Saham perusahaan sub sektor konstruksi bangunan yang terdaftar di Bursa Efek Indonesia tahun 2016-2018. Hipotesis ketiga yang mengatakan ROE berpengaruh positif terhadap Return Saham perusahaan sub sektor konstruksi bangunan yang terdaftar di Bursa Efek Indonesia tahun 2016-2018 ditolak. Hal ini dibuktikan dengan nilai koefisien sebesar 0,007205 dan nilai probabilitas sebesar 0,3563 yang lebih besar dari nilai signifikansi $5 \%(0,3563>0,05)$.

4. Rasio likuiditas Current Ratio (CR) yang dimediasi oleh Return On Equity (ROE) terhadap Return Saham menunjukkan hasil bahwa terdapat pengaruh positif dan tidak signifikan CR terhadap Return Saham yang dimediasi oleh return on equity perusahaan sub sektor konstruksi bangunan yang terdaftar di Bursa Efek Indonesia tahun 2016-2018. Hipotesis keempat yang mengatakan bahwa return on equity 
Pengaruh Likuiditas (Current Ratio) Terhadap Return Saham: Peran Pemediasi Profitabilitas (Return On Equity) Pada Perusahaan Sub Sektor Konstruksi Bangunan Di Bursa Efek Indonesia Periode 2016-2018

berperan sebagai pemediasi pada pengaruh positif current ratio terhadap Return Saham perusahaan sub sektor konstruksi bangunan yang terdaftar di Bursa Efek Indonesia tahun 2016-2018 ditolak. Hal ini dibuktikan dengan nilai koefisien sebesar 0,007805 dan nilai probabilitas sebesar 0,2607 yang lebih kecil dari nilai signifikansi 5\% (0,2607 > $0,05)$.

\section{Saran}

1. Bagi peneliti berikutnya yang akan meneliti dengan topik sejenis sebaiknya menggunakan variabel independen selain Current Ratio (CR) seperti Quick Ratio, Debt to Asset Ratio, Cash Ratio, Net Profit Margin, Debt to Equity Ratio, Price Book Value yang mungkin dapat digunakan untuk menguji pengaruh terhadap Return Saham.

2. Memperluas jumlah sampel dan memperpanjang periode penelitian agar diperoleh hasil yang lebih baik.

3. Selain menggunakan variabel independen yang lain, alangkah baiknya untuk penelitian berikutnya mengambil obyek penelitian pada sub sektor selain konstruksi bangunan, seperti pertanian, pertambangan, perbankan, dll.

\section{DAFTAR PUSTAKA}

Absari, Dyatri Utami Arian, dkk. (2012). Analisis Pengaruh Faktor Fundamental Perusahaan Dan Risiko Sistematis Terhadap Return Saham. Jurnal Akuntansi, Vol. 3 No. 2 Juli 2012. Universitas Islam Negeri, Malang.

Andansari, Neni Awika, dkk. (2016). Pengaruh Return On Equity (ROE), Price Earning Ratio (PER), Total Asset Turnover (TATO) Dan Price To Book Value (PBV) Terhadap Return Saham (Studi Kasus Pada
Perusahaan Manufaktur Sektor Makanan Dan Minuman Yang Terdaftar Di BEI Periode 20082014). Journal Of Accounting, Vol. 2 No. 2 Maret 2016. Universitas Pandanaran, Semarang.

Ang, Robert. (1997). Buku Pintar Pasar Modal Indonesia. Jakarta: Media Staff.

Aryaningsih, Yuni Nur, dkk. (2018). Pengaruh Return On Asset (ROA), Return On Equity (ROE) Dan Earning Per Share (EPS) Terhadap Return Saham Pada Perusahaan Consumer Good (Food And Baverages) Yang Terdaftar Di Bursa Efek Indonesia (BEI) Periode 20132016. Journal Of Management, Vol. 4 No.4 2018. Universitas Pandanaran, Semarang.

Besley, Scott dan Brigham Eugene F. (2008). Essentials of Managerial Finance. USA: South-Western.

Brigham, Eugene F. Dan Houston. (1999). Manajemen Keuangan. Jakarta: Erlangga.

Brigham, Eugene F. Dan Houston. (2006). Fundamental of Financial Management: Dasar-Dasar Manajemen Keuangan. Edisi 10. Jakarta: Salemba Empat.

Brigham, Eugene F dan Houston, J,F. (2012). Dasar-Dasar Manajemen Keuangan. Edisi Kesepuluh. Jakarta: Erlangga. 
Choirurodin. (2018). Pengaruh Current Ratio, Return On Equity, Debt To Equity Ratio Terhadap Return Saham (Pada Perusahaan Food And Baverages Yang Terdaftar Di BEI Periode 2013-2016). Skripsi. Universitas Negeri, Yogyakarta.

Darmadji, Tjiptono dan Fakhrudin Hendi. (2012). Pasar Modal di Indonesia. Edisi Ketiga. Jakarta: Salemba Empat.

Fahmi, Irham. (2012). Analisis Laporan Keuangan. Cetakan Kedua. Bandung: Alfabeta.

Ghozali, Imam. (2011). Aplikasi Analisis Multivariate denga Program IBM SPSS 19. Edisi Kelima. Semarang: Universitas Diponegoro.

Halin, Hamid. (2016). Pengaruh Rasio Lancar Dan Rasio Hutang Terhadap Profitabilitas Pada Industri Telekomunikasi Yang Listing Di Bursa Efek Indonesia. Jurnal Ilmiah Ekonomi Global Masa Kini, Vol. 7 No. 1 Desember 2016. Universitas Indo Global Mandiri, Palembang.

Harahap, Sofyan Syafri. (2011). Analisis Kritis atas Laporan Keuangan. Jakarta: PT. Raja Grafindo Persada.

Harjito, Agus dan Martono. (2014). Manajemen Keuangan. Yogyakarta: Ekonesia.

Hidajat, Natasya Cindy. (2018). Pengaruh Return On Equity, Earning Per Share, Economic Value Added, Dan Market Value Terhadap Return Saham Perusahaan Sektor Pertanian Yang Terdaftar Di Bursa Efek
Indonesia Periode 2010-2016. Jurnal Ekonomi, Vol. 23 No. 1 Maret 2018. Universitas Tarumanegara.

Jama'an. (2008). Pengaruh Mekanisme Corporate Governance dan Kualitas Kantor Akuntan Publik Terhadap Integritas Informasi Laporan Keuangan (Studi Pada Perusahaan Publik Di BEJ). Tesis. Universitas Diponegoro Semarang.

Jogiyanto. (2014). Teori Portofolio dan Analisis Investasi. Edisi 10. Yogyakarta: BPFE.

Jumingan. (2006). Analisis Laporan Keuangan. Cetakan Pertama. Jakarta: Bumi Aksara.

Kartikaningsih, Desi. (2013). Pengaruh Debt Ratio, Current Ratio, Total Asset Turnover, Size Perusahaan Dan Net Profit Margin Terhadap Return On Equity (Studi Kasus Pada Perusahaan Manufaktur Yang Terdaftar Di Bursa Efek Indonesia Pada Tahun 2009-2013). Jurnal Akuntansi, Vol. 1 No.2 Desember 2013. Universitas Sarjanawiyata Tamansiswa, Yogyakarta.

Kasmir. (2013). Analisis Laporan Keuangan. Jakarta: Rajawali Pers.

Kuncoro, Mudrajat. (2011). Metode Kuantitatif. Yogyakarta: STIM YKPN.

Kusuma, Desta Rizky dan Deny Ismanto. (2012). Modul PraktiumEviews. Yogyakarta: Manajemen Universitas Ahmad Dahlan.

Martalena dan Maya Malinda. (2011). Pengantar Pasar Modal. Bandung: Andi. 
Pengaruh Likuiditas (Current Ratio) Terhadap Return Saham: Peran Pemediasi Profitabilitas (Return On Equity) Pada Perusahaan Sub Sektor Konstruksi Bangunan Di Bursa Efek Indonesia Periode 2016-2018

Munawir, S. (2010). Analisis Laporan Keuangan. Edisi Keempat Cetakan Kelima Belas. Yogyakarta: Liberty.

Murhadi, W. R. (2013). Analisis Laporan Keuangan, Proyeksi dan Valuasi Saham. Jakarta: Salemba Empat.

Notoatmodjo, Soekidjo. (2003). Metodologi Penelitian Kesehatan. Jakarta: Rineka Cipta.

Riyanto, Bambang. (2001). Dasar-Dasar Pembelanjaan Perusahaan. Yogyakarta: BPFE.

Ross, Jordan Westerfield. (2008). Pengantar Keuangan Perusahaan (Corporate Finance Fundamental), Jakarta: Salemba Empat.

Samsul, Mohammad. (2006). Pasar Modal dan Manajemen Portofolio. Jakarta: Erlangga.

Sawir, Agnes. (2003). Analisis Kinerja Keuangan dan Perencanaan Keuangan Perusahaan. Jakarta: Gramedia Pustaka Utama.

Sawir, A. (2009). Analisis Kinerja Keuangan dan Perencanaan Keuangan Perusahaan. Jakarta: PT Gramedia Pustaka Utama.

Stice, Earl K, Stice James D, Fred Skousen. (2009). Intermediate Accounting. USA.

Suantari, Ni Luh Putu, dkk. (2016). Pengaruh Current Ratio (CR), Debt To Equity Ratio (DER), Return On Equity Ratio (ROE), Inflasi Dan Tingkat Suku Bunga Terhadap Return Saham Pada Perusahaan
Manufaktur Yang Terdaftar Di Bursa Efek Indonesia (BEI) Periode 20102015. Jurnal Riset Akuntansi, Vol. 6 No. 4 September 2016. Universitas Mahasaraswati, Denpasar.

Sugiarti, dkk. (2015). Pengaruh Kinerja Keuangan Perusahaan Terhadap Return Saham (Studi Pada Perusahaan Manufaktur Yang Terdaftar Di Bursa Efek Indonesia). Jurnal Aplikasi ManajemenI (JAM), Vol. 13 No. 2 (2015). Universitas Brawijaya, Malang.

Sugiyono. (2005). Metode Penelitian Administrasi. Bandung: Alfabeta.

Supomo, Bambang dan Nur Indriantoro. (2002). Metodologi Penelitian Bisnis. Cetakan Kedua. Yogyakara: Penerbit BFEE UGM.

Tandelilin, Eduardus. (2010). Portofolio dan Investasi: Teori dan Aplikasi. Edisi Pertama. Yogyakarta: Kanisius.

Tulasi, Daniel. (2006). Cash Flow Ratios Analysis Sebagai Metode Pengukuran Kinerja Keuangan Perusahaan. Manajemen Usahawan Indonesia (Oktober).

Tumonggor, Mutiara, dkk. (2017). Analisis Pengaruh Current Ratio, Return On Equity, Debt To Equity Ratio Dan Growth Terhadap Return Saham Pada Cosmetic And Household Industry Yang Terdaftar Di BEI Periode 2010-2016. Jurnal EMBA, Vol.5 No.2 Juni 2017. Universitas Sam Ratulangi, Manado. 
JURNAL FOKUS • VOLUME 10 No. $1 \bullet$ Maret 2020

P-ISSN: 2088-4079 | E-ISSN: 2716-0521

Whitney, F. L. (1960). The Elements of Resert. Asian Eds. Osaka: Overseas Book Co.

Widarjono, Agus. (2009). Ekonometrika Pengantar dan Aplikasinya. Edisi Ketiga. Yogyakarta: Ekonesia. 